\title{
Fate of a phytoplankton spring bloom: sedimentation and carbon flow in the planktonic food web in the northern Baltic
}

\author{
R. Lignell *, A.-S. Heiskanen, H. Kuosa, K. Gundersen**, P. Kuuppo-Leinikki, \\ R. Pajuniemi, A. Uitto
}

Tvärminne Zoological Station, SF-10900 Hanko, Finland

\begin{abstract}
During the spring bloom in 1988, the dynamics of planktonic carbon flow were studied weekly in the euphotic layer in the northern Baltic. The spring bloom developed after the formation of a slight vertical salinity gradient near the surface at the end of April, and a peak in phytoplankton primary productivity and biomass (dominated by the dinoflagellate Peridiniella catenata) was reached about $1 \mathrm{wk}$ later. The biomass of all heterotrophic compartments, especially that of bacteria and copepods, increased strongly during the peak and declining phases of the algal bloom, showing that their success was closely linked with the bloom. During the whole bloom period, the integra! primary production $\left({ }^{14} \mathrm{C}\right.$ incorporation) was $45.5 \mathrm{~g} \mathrm{C} \mathrm{m}^{-2}$, and 'new' $\left(\mathrm{NO}_{3}^{-}-\mathrm{N}\right.$-based) production contributed about $80 \%$ of this value. The rotifers-copepods grazing chain and the bacteria-heterotrophic nanoflagellates-ciliates 'microbial loop' consumed directly about the same amount $\left(3.5 \mathrm{~g} \mathrm{C} \mathrm{m}^{-2}\right)$ of phytoplankton carbon. Algae accounted for $64 \%$ of the total carbon consumption of zooplankton. Sedimentation corresponded to $72 \%$ of the primary production. The sum of algal biomass increase and loss factors (exudation, grazing and sedimentation) was $94 \%$ of the integral primary production, which supports our conclusion that there is a strong imbalance between primary and secondary production in the vernal planktonic food web off the SW coast of Finland.
\end{abstract}

\section{INTRODUCTION}

Phytoplankton primary production is by far the most important biological energy source in most of the Baltic (Elmgren 1984). In the northern Baltic, the course of the phytoplankton biomass follows the unimodal (occasionally bimodal) annual cycle generally observed in temperate and polar areas (Niemi 1975), whereas in the southern Baltic several phytoplankton peaks commonly occur during the season of algal growth (Smetacek et al. 1984).

In winter in the Baltic Sea, the biomass of both autotrophic and heterotrophic plankton communities is low (Niemi 1975, Kuparinen et al. 1984, Smetacek et

Present addresses:

- Department of Limnology, University of Helsinki, SF-00710 Helsinki, Finland

- Bermuda Biological Station for Research, Inc., Ferry Reach, GE 01, Bermuda al. 1984, Kivi 1986). During spring in cold waters, the generation times of phytoplankton are considerably shorter than those of its most important grazers, and thus grazing usually does not control the development of the algal assemblage once conditions become favourable for growth (Colebrook 1984). As a result, the phytoplankton biomass increases until it becomes limited by nutrients (in the northern Baltic the availability of both nitrogen and phosphorus becomes very low; Lignell et al. 1992), after which a major part of the bloom settles out of the mixed layer (Kuparinen et al. 1984, Smetacek et al. 1984). The sedimentation of this material probably constitutes the most important input of the year for much of the benthic fauna (Elmgren 1984), and even though the metazooplankters (rotifers and copepods) seem to be unable to effectively exploit the spring bloom, it is nevertheless important for these organisms also, as a trigger for reproduction (Peinert et al. 1982). Moreover, although grazing by protozooplankton (heterotrophic nano- 
flagellates, ciliates and heterotrophic dinoflagellates) and metazooplankton is too limited to control phytoplankton biomass development, it may strongly affect the phytoplankton species composition during spring (Bathmann et al. 1990).

Nutrients are not the only important factor controlling the spring bloom. Levasseur et al. (1984) showed that the phytoplankton succession was hierarchically controlled by the water-column stability conditions, mean light in the mixed layer and temperature in the St. Lawrence Estuary, Canada, where nutrients remain abundant throughout the year. According to Smetacek \& Passow (1990), the critical factor for spring bloom initiation is that the period of temporary stabilization of a shallow surface layer is long enough to permit algal cells to accumulate and outgrow their grazers. Moreover, Laws et al. (1988) argued that the vernal phytoplankton biomass was limited by nitrate in Auke Bay, Alaska, while under the prevailing nutrient-sufficient conditions the phytoplankton growth rates seemed to be limited by either irradiance or temperature. In general, if the autogenic succession is not frequently interrupted by stochastic hydrographic events, the succession will progress from a growth-oriented strategy in the spring to an equilibrium-oriented one in the summer (Amblard 1988), the former period being predominantly based on 'new' production sensu Dugdale \& Goering (1967) and the latter on regenerated production.

In temperate waters, the vernal phytoplankton bloom represents an important and clearly defined stage in the annual pelagic growth cycle, and knowledge of its dynamics is necessary for understanding the qualitative and quantitative aspects of the functioning of the pelagic ecosystem. Moreover, the balance between primary and secondary production largely determines how much of the initial vernal nutrient pool is retained in the mixed layer after the decline and sedimentation of the algal bloom. The fate of the spring bloom may vary, as it seems that in the nor thern North Sea (Williams \& Lindley 1980) and in the northern Atlantic Ocean (Colebrook 1984) the vernal phytoplankton production is consumed by zooplankton overwintering in deep offshore waters, or that instead of sinking to the bottom a part of the bloom may remain in the mixed layer as dead particulate and dissolved organic carbon (Larsson et al. 1986).

A joint ecosystem study on the spring bloom dynamics was carried out as part of the project PELAG in 1988, in the coastal area of the northern Baltic proper. Special emphasis was given to the relative importance of the algae-metazooplankton grazing chain, bacteriaheterotrophic nanoflagellates - ciliates 'microbial loop' and sedimentation as alternative routes for phytoplankton carbon. An outline of the results is presented here, while detailed reports on specific issues will be presented separately.

\section{MATERIAL AND METHODS}

Hydrobiology of the study area. The study area was located in the outer coastal zone, seaward of the Tvärminne archipelago, off the SW coast of Finland (Fig. 1). Upwellings and downwellings typically occur in the Tvärminne area (Niemi 1975). The area is not affected by large sewage outlets. The sampling site (Storgadden; Fig. 1) is $46 \mathrm{~m}$ deep with no permanent halocline and a salinity and $\mathrm{pH}$ of about $6 \%$ and 8 , respectively. A more detailed description of the hydrography in the area is presented by Niemi (1975).

The seasonal dynamics of the nutrients, phytoplankton, bacterioplankton and zooplankton in the Tvärminne area are well known (Niemi 1975, Kuparinen et al. 1984, Kivi 1986, Lignell 1990, and references in these works). The net (particulate plus dissolved) primary production in the area ranges from 74 to $111 \mathrm{~g} \mathrm{C} \mathrm{m}^{-2} \mathrm{yr}^{-1}$, and the bacterial secondary production amounts to 10 to $15 \%$ of it (Kuparinen 1984, Kuosa \& Kivi 1989, Lignell 1990). The production of large $(>150 \mu \mathrm{m})$ zooplankters is about $10 \mathrm{~g} \mathrm{C} \mathrm{m}^{-2} \mathrm{yr}^{-1}$ (Kuparinen et al. 1984).

Measurements. During the spring bloom, from 29 March to 26 May 1988, the Storgadden station was sampled at about weekly intervals (first interval $2 \mathrm{wk}$ ), using a 101 water sampler. The sampling depths were $0,2.5,5$ and $10 \mathrm{~m}$ (approximately covering the euphotic layer), except for the in situ primary productivity measurements, for which sampling/incubation depths of $0.2,1,2.5,5,7$ and $9 \mathrm{~m}$ were used. At the same time, the vertical distribution of temperature, salinity and light attenuation (Mavolux underwater light meter) in the water column was measured.

Primary productivity. Primary productivity was measured by the ${ }^{14} \mathrm{C}$ method (Steemann Nielsen 1952). $\mathrm{NaH}^{14} \mathrm{CO}_{3}$ at $5 \mu \mathrm{Ci}$ (specific activity of the undiluted stock $57.8 \mathrm{mCi} \mathrm{mmol}^{-1}$ i Amersham, UK) was added to $100 \mathrm{ml}$ glass bottles. Duplicate light bottles were used at each incubation depth and duplicate dark bottles at 2.5 and $7 \mathrm{~m}$. The incubations were started at 10:00 to 11:00 h and lasted for $24 \mathrm{~h}$.

All radioactivity measurements were performed with LumaGel scintillation cocktail (Lumac) and an LKB Rackbeta 1215 liquid scintillation counter, using the external standard channel ratio method. In all ${ }^{14} \mathrm{C}$ primary productivity and exudation calculations, the dark values were subtracted from the corresponding light values. Dissolved inorganic carbon was measured with an infrared carbon detector (Elektro-Dynamo carbon analyzer)

Size fractionation of ${ }^{14} \mathrm{C}$ samples: Net primary productivity (particulate plus dissolved organic ${ }^{14} \mathrm{C}$ ) was measured by allowing an acidified $4 \mathrm{ml}$ subsample $(\mathrm{pH}<2)$ to stand open for $24 \mathrm{~h}$ (no bubbling) before radioactivity measurements (Niemi et al. 1983). 


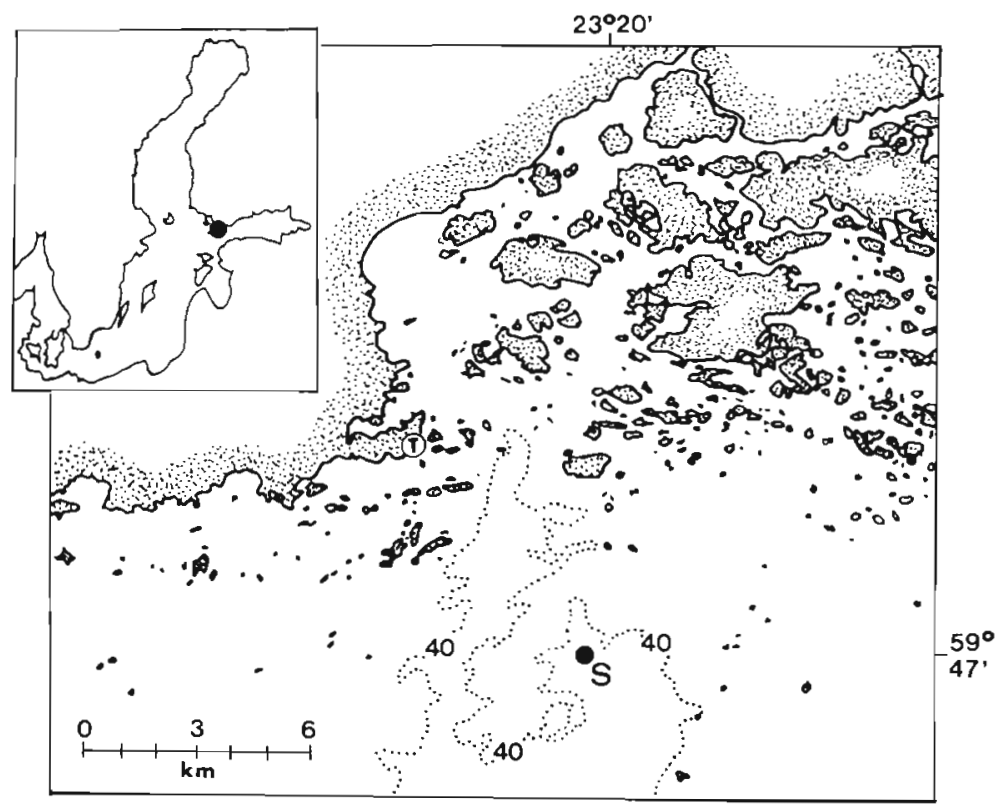

Fig. 1. Study area and Storgadden sampling station (S) off the SW coast of Finland. Schematic $40 \mathrm{~m}$ isobaths are marked with a dotted line. T: Tvärminne Zoological Station

Algal excretion of organic carbon (exudation) was measured at $1,2.5$ and $5 \mathrm{~m}$. In order to ensure gentle removal of algal cells from the water phase, the net exudate pool was measured on the $<0.2 \mu \mathrm{m}$ filtrate (Sartorius) of the supernatant of a centrifuged sample (10 min at $3000 \times g$, in situ temperature). Bacterial incorporation of ${ }^{14} \mathrm{C}$ exudates was measured on $<1.0 \mu \mathrm{m}$ filtrates (Nuclepore), corrected for net exudation, for $<1.0 \mu \mathrm{m}$ autotrophic production $(<1.0 \mu \mathrm{m}$ prefiltered sample) and for the proportion of bacterial activity in the $>1.0 \mu \mathrm{m}$ fraction (total ${ }^{3} \mathrm{H}$-thymidine uptake) (Lignell 1990)

Bacterial productivity. Net bacterial productivity was measured from tritiated thymidine incorporation (TTI) into material precipitable with cold trichloroacetic acid (TCA) (Fuhrman \& Azam 1982). A saturating (10 nmol) concentration of ${ }^{3} \mathrm{H}$-thymidine (specific activity 38 to $44 \mathrm{Ci} \mathrm{mmol}^{-1}$; Amersham) was added to $20 \mathrm{ml}$ scintillation vials (duplicates from each sampling depth and 1 duplicate set of formalin-killed blanks). The TTI samples were incubated for about $1 \mathrm{~h}$ at in situ temperature; they were started simultaneously with the ${ }^{14} \mathrm{C}$ incubations and terminated with formalin

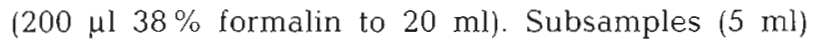
were extracted for 0.5 to $1 \mathrm{~h}$ with $5 \mathrm{ml} 10 \%$ TCA in icecold conditions and then filtered on $0.2 \mu \mathrm{m}$ cellulose acetate filters (Sartorius). The filters were rinsed with $5 \%$ ice-cold TCA before radioactivity measurements.

Net bacterial productivity was calculated using a mean bacterial cell volume of $0.063 \mu \mathrm{m}^{3}$ found during spring in our study area by Kuparinen (1988), a ${ }^{3} \mathrm{H}-$ thymidine conversion factor of $1.1 \times 10^{18}$ cells $\mathrm{mol}^{-1}$ (Riemann et al. 1987), and a carbon content of $0.27 \mathrm{pg} \mathrm{C} \mu \mathrm{m}^{-3}$ (Kuparinen 1988).

Biomass determinations. Plankton organisms were identified and their wet weight determined on either separate (all heterotrophs and picoalgae) or pooled (large algae) samples covering the surface layer $(0$ to $10 \mathrm{~m})$. The metazooplankton samples (rotifers, crustaceans and pelagic larvae of bivalves) were preserved with formalin (final conc. $4 \%$ ) and large algae, ciliates, and heterotrophic dinoflagellates with acid Lugol's solution (final conc. ca $0.3 \%$. The samples were counted according to the method of Utermöhl (1958), using phase contrast microscopy. Nanoflagellates were preserved with unbuffered glutaraldehyde (final conc. 1\%) and stained with proflavine (Haas 1982); they were counted with an epifluorescence microscope within $2 \mathrm{~d}$, and heterotrophic and autotrophic organisms were distinguished on the basis of the red autofluorescence of chlorophyll a (Davis \& Sieburth 1982). Picoplanktonic cyanobacteria were enumerated in unpreserved samples with an epifluorescence microscope (KuuppoLeinikki \& Kuosa 1989). Bacteria were preserved with formaldehyde (final conc. 1\%) and stained with acridine orange (Hobbie et al. 1977).

Wet weight values were transformed to carbon values, using a coefficient of 0.27 for bacteria (Kuparinen 1988), 0.22 for flagellates (Børsheirn \& Bratbak 1987), 0.05 for metazooplankton (Mullin 1969) and 0.1 for other organisms (see Peters \& Downing 1984). The nomenclature of phytoplankton follows Edler et al. (1984).

Sedimentation. On 30 April, sediment traps $11 \mathrm{~m}$ high cylinders with a height:diameter ratio of 10 ) were moored below the mixed layer at $30 \mathrm{~m}$ depth, and sampled at about $1 \mathrm{wk}$ intervals. In addition, daily sedimentation (for one $24 \mathrm{~h}$ period) was measured on 29 to 30 March. Sedimentation for the periods without moored traps was estimated on the basis of the weekly values measured for particulate organic carbon (POC) using a linear regression model, which described adequately $\left(\mathrm{r}^{2}=86 \%\right)$ the relation between the settled $\mathrm{POC}$ and the mean POC concentration in the water column above the traps on 11 occasions during spring and summer 1988 (Heiskanen \& Gundersen unpubl.).

Sedimentation was measured both with and without preservation of the settled material; in the former case, preservation took place with $50 \mathrm{ml} 37 \%$ formaldehyde, which diffused from an external reservoir into the bottom of the cylinder (Heiskanen \& Gundersen unpubl.). 
Subsamples of the settled material were filtered onto precombusted $\left(450^{\circ} \mathrm{C}\right.$ overnight) Whatman $\mathrm{GF} / \mathrm{F}$ glass-fibre filters, the filters were dried and stored at room temperature, and their $\mathrm{POC}$ content was determined with a Heraeus CHN-O-Rapid elemental analyser. The proportions of different phytoplankton taxa in the sedimented material were calculated by microscopy (Utermöhl 1958).

Estimation oi zooplankton grazing. Growth rates, productivity and grazing values for protists and metazooplankters were estimated from the corresponding biomass development between the weekly samplings as follows.

Under the ice (from 29 March to 13 April), the proportion of zooplankton production based on newly produced photosynthates was assumed to be quantitatively of small importance. During the ice-free period of the spring bloom (from 13 April to 26 May), the growth rate of the ciliate assemblage was estimated on the basis of its size distribution, using the regression equation presented by Finlay (1977) for ciliate growth at $8.5^{\circ} \mathrm{C}$. The ciliate growth rates were then corrected for temperature, assuming a $Q_{10}$ value of 2 and using the formula

$$
k_{\mathrm{AT}}=k_{85} \times \mathrm{Q}_{10}{ }^{(\mathrm{AT}-8.5) / 10}
$$

where $k_{\mathrm{AT}}$ and $k_{8.5}$ are growth rates at the ambient temperature (AT) and $8.5^{\circ} \mathrm{C}$, respectively.

The growth rate $(k)$ of the other protist groups was calculated using the formula

$$
k=\left(\ln C_{t}-\ln C_{0}\right) / t
$$

where $t$ is the sampling interval $(7 \mathrm{~d})$ and $C_{0}$ and $C_{l}$ are the carbon biomass values at the beginning and end of the $7 \mathrm{~d}$ period.

The productivity $(P)$ of the protists was then estimated using the formula

$$
P=k_{\max } \times B \times t
$$

where $B$ is the mean biomass between samplings:

$$
B=\left(C_{t}-C_{0}\right) /\left(\ln C_{t}-\ln C_{0}\right) .
$$

Heterotrophic nanoflagellates and heterotrophic dinoflagellates were assumed to be controlled from 'above' by larger zooplankters, and hence the maximum growth rate $\left(k_{\max }\right)$ recorded during the study was applied for all sampling periods. The total seasonal production of all protist groups was calculated as the integral sum of consecutive productivity values.

Predation on copepods was assumed to be weak during the whole study, and hence their production between 13 April and 26 May was estimated from the corresponding biomass increase. During the growing phase of the bloom (from 13 April to 5 May), the production of rotifers was estimated from their biomass increase, whereas during the declining phase from 5 to 26 May), a stronger control from 'above' by predators was assumed and the production of rotifers was estimated analogously to that of heterotrophic flagellates (see above).

The carbon demand (total grazing) of zooplankton was estimated by assuming a gross growth efficiency of $40 \%$ for heterotrophic nanoflagellates (Fenchel 1982) and ciliates (Heinbokel 1978, Sheldon et al. 1986), 50\% for heterotrophic dinoflagellates (Goldman et al. 1989; calculated from Figs. 1 to 3), and $25 \%$ for metazooplankton (Cole et al. 1988). Moreover, it was assumed that $25 \%$ of the total carbon ingested by metazooplankton was released as dissolved organic carbon (DOC; Copping \& Lorenzen 1980). Finally, assuming an assimilation efficiency of $60 \%$ for metazooplankters (Laws et al. 1988), 20\% of their total carbon consumption was estimated to settle out of the euphotic layer as POC in faecal pellets

Predator-prey relationships in the plankton community. Planktonic carbon flow was estimated by assuming that the alternative routes of organic carbon produced in algal photosynthesis were sedimentation, the phytoplankton-rotifers-copepods 'grazing food chain' and the bacteria - heterotrophic nanoflagellates - ciliates and heterotrophic dinoflagellates 'microbial loop' (Azam et al. 1983) (see Fig. 4). Furthermore, the carbon flow model was based on the assumptions that the different zooplankton groups preferably consumed organisms about 1 order of magnitude smaller than themselves (Sheldon et al. 1972, Azam et al. 1983) within the ranges reported for prey size (for details see 'Discussion'), and that they consumed both auto- and heterotrophic organisms, hence forming a food web.

\section{RESULTS}

In 1988, the ice cover broke up in early April, and the melting of the ice was associated with a clear decrease in salinity near the surface (Fig. 2A). Then a small upwelling took place and the upper water column became virtually homogeneous until the end of April, when a slight salinity increase of $0.04 \%$ was recorded from 0 to $5 \mathrm{~m}$ depth (due to its smallness the increase does not show in Fig. 2A). At the end of April, the temperature in the whole water column was $1{ }^{\circ} \mathrm{C}$ (Fig. 2B), and thereafter the surface layer gradually warmed up, which resulted in the formation of a thermocline at 10 to $15 \mathrm{~m}$ depth in the middle of May. At the end of May, a vigorous upwelling took place as a consequence of strong western winds and it disrupted the development of thermal stratification (Fig. 2). The upwelling marked the end of the spring bloom period. 


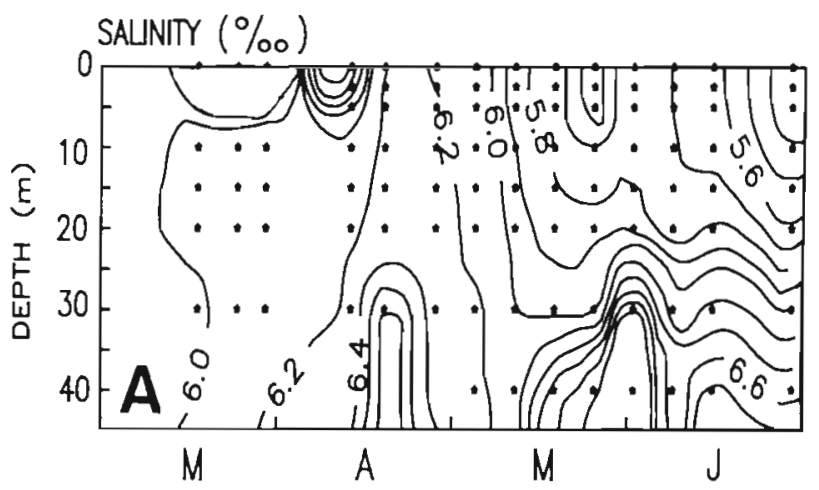

TEMPERATURE $\left({ }^{\circ} \mathrm{C}\right)$

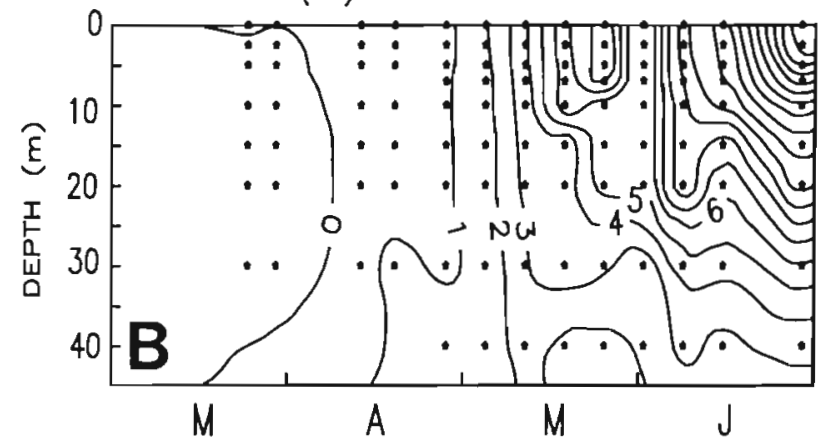

Fig. 2. (A) Salinity and (B) temperature of the water column during the spring bloom in 1988 at Storgadden station

\section{Phytoplankton succession, temporal course of plankton biomass and productivity, and sedimentation}

The vernal phytoplankton bloom was dominated by the dinoflagellates Peridiniella catenata (Levander) Balech (syn. Gonyaulax catenata) and Gymnodinium sp., which constituted from 60 to $90 \%$ of the total algal biomass. Autotrophic Mesodinium rubrum Lohmann, which was by far the most abundant ciliate, is included in the phytoplankton data (Fig. 3A). After the break-up of the ice cover in early April, the algal assemblage started to increase and it reached its biomass peak on 19 May (7.1 $\mathrm{g} \mathrm{C} \mathrm{m}^{-2}$; Fig. 3A), about 1 wk after the exhaustion of nutrients (particularly $\mathrm{NO}_{3}{ }^{-} \mathrm{N}$ ) in the mixed layer. Net primary productivity closely paralleled the algal biomass development, but it reached its maximum $\left(1.8 \mathrm{~g} \mathrm{C} \mathrm{m}^{-2} \mathrm{~d}^{-1}\right)$ earlier, on $5 \mathrm{May}$, having another smaller peak $\left(1.4 \mathrm{~g} \mathrm{C} \mathrm{m}^{-2} \mathrm{~d}^{-1}\right)$ on 19 May.

After the culmination of the bloom at the end of May, the phytoplankton biomass decreased rapidly (Fig. 3A), and the diatom Skeletonema costatum (Greville) Cleve became abundant, amounting to over $40 \%$ of the total algal biomass. The net primary productivity values also declined steeply to typically low summer levels $\left(0.2\right.$ to $\left.0.4 \mathrm{~g} \mathrm{C} \mathrm{m}^{-2} \mathrm{~d}^{-1}\right)$.
At the beginning of May, the biomass of bacteria and protists started to increase together with the temperature and phytoplankton biomass (Figs. 2 \& 3). The metazooplankton biomass, consisting mainly of naupliar and early copepodite stages of Acartia spp., and the rotifer Synchaeta littoralis Rousselet, also increased strongly after the beginning of May (Fig. 3B).

The biomass of rotifers attained a peak value first (on 12 May; $0.20 \mathrm{~g} \mathrm{C} \mathrm{m}^{-2}$ ). Then on 19 May, a biomass maximum was recorded for heterotrophic nanoflagellates $\left(0.45 \mathrm{~g} \mathrm{C} \mathrm{m}^{-2}\right)$ and ciliates and heterotrophic dinoflagellates $\left(0.21 \mathrm{~g} \mathrm{C} \mathrm{m}^{-2}\right)$. The biomass of bacteria and $>200 \mu \mathrm{m}$ zooplankton (mainly copepods with a few pelagic larvae of bivalves) peaked about $1 \mathrm{wk}$ later (0.91 and $0.69 \mathrm{~g} \mathrm{C} \mathrm{m}^{-2}$; Fig. 3B). At this stage the copepod community was dominated by adult Acartia spp. females, while the proportion of nauplii and early copepodites was small.

Traps with and without formalin preservation gave integral vernal sedimentation values of 38.1 and
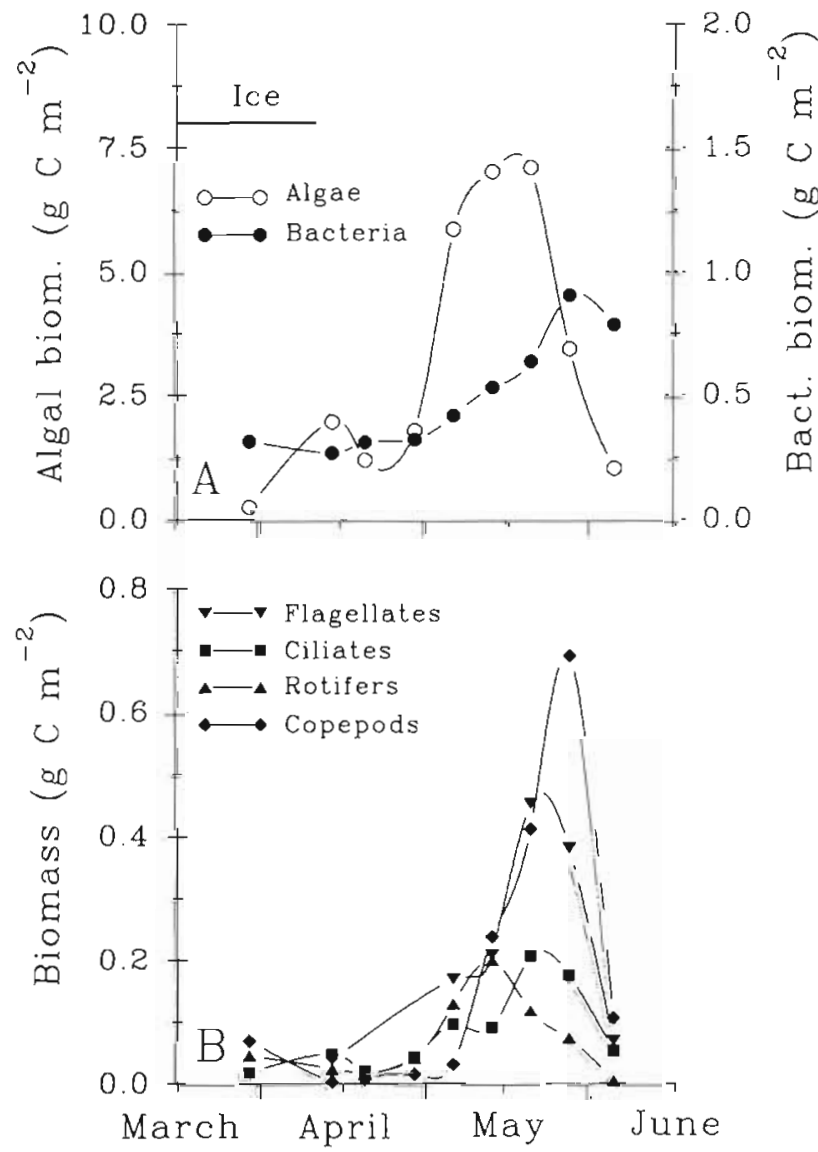

Fig. 3. Development of the standing stocks $\left(\mathrm{g} \mathrm{C} \mathrm{m}^{-2}\right)$ of (A) phytoplankton and bacterioplankton, and (B) heterotrophic nanoflagellates, ciliates, rotifers and copepods, during the spring bloom in 1988 at Storgadden station. Note the different scales in biomass ( $y$-axes) for algae, bacteria and zooplankters 
$26.3 \mathrm{~g} \mathrm{C} \mathrm{m} \mathrm{m}^{-2}$, respectively. When not otherwise stated, the sedimentation values presented in this study represent those obtained with formalin preservation of settled POC, corrected for the 'excess' contribution of POC by the motile dinoflagellate Peridiniella catenata (difference in $P$. catenata carbon between traps with and without preservation). During different sampling periods the 'excess' biomass of $P$. catenata accounted for between 2 and 24 percentage points of the difference in POC between the 2 traps.

During the period from 13 to 18 May, the highest sedimentation rate of $1.9 \mathrm{~g} \mathrm{C} \mathrm{m}^{-2} \mathrm{~d}^{-1}$ was recorded, and this was also associated with the highest proportion of 'excess' Peridiniella catenata carbon in traps with formalin preservation. By the end of May (from 26 May to 1 June), the sedimentation rate had declined to $0.7 \mathrm{~g} \mathrm{C} \mathrm{m}^{-2} \mathrm{~d}^{-1}$.

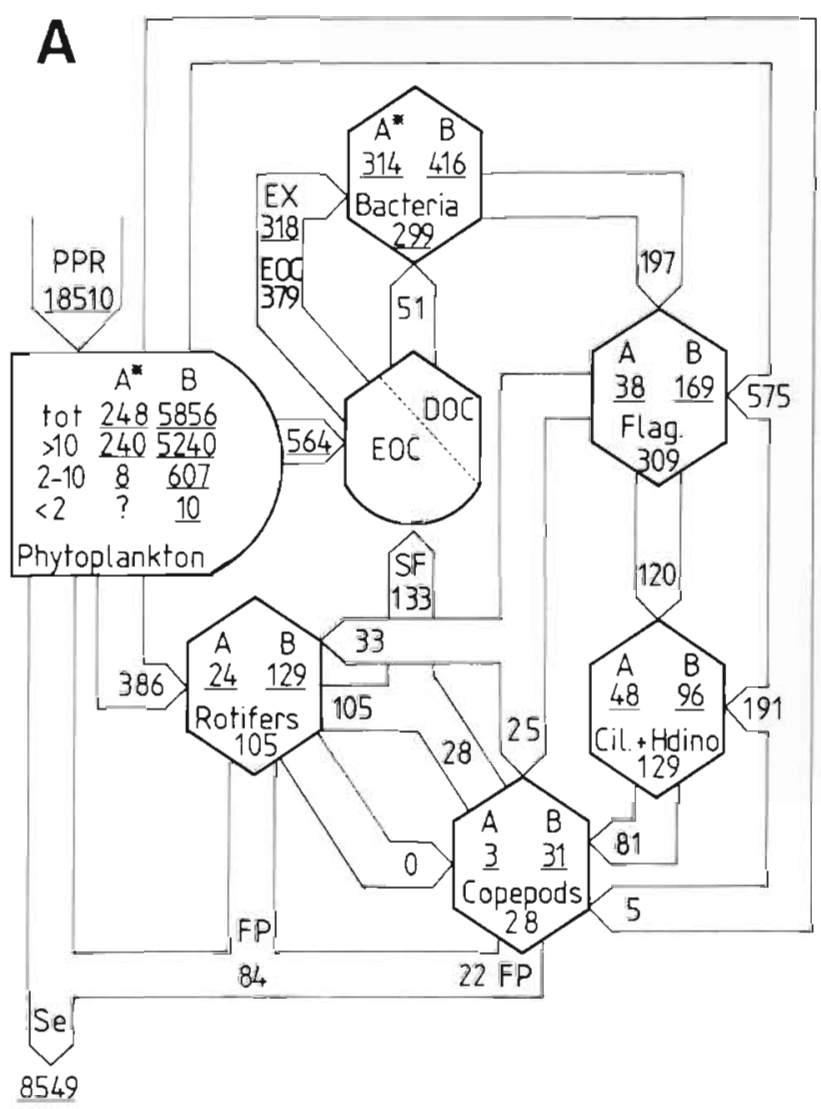

\section{Dynamics of carbon flow during the spring bloom}

Growing phase

During the period from 29 March to 5 May (primary productivity maximum), the integral net primary production amounted to $18.5 \mathrm{~g} \mathrm{C} \mathrm{m}^{-2}$, resulting in an algal biomass increase from 0.25 to $5.86 \mathrm{~g} \mathrm{C} \mathrm{m}^{-2}$ (Fig. 4A). Sedimentation losses were $8.5 \mathrm{~g} \mathrm{C} \mathrm{m}^{-2}$. The biomass of the heterotrophic compartments started to increase from low winter levels, but the total carbon consumption of zooplankton was still small (about $9 \%$ of net primary production; Fig. 4A). The assumption of the small importance of zooplankters in consuming newly photosynthesized carbon under the ice was supported by the observation that from 29 March to 13 April, the increase in algal biomass, exudation and sedimentation accounted for the whole of the integral primary production

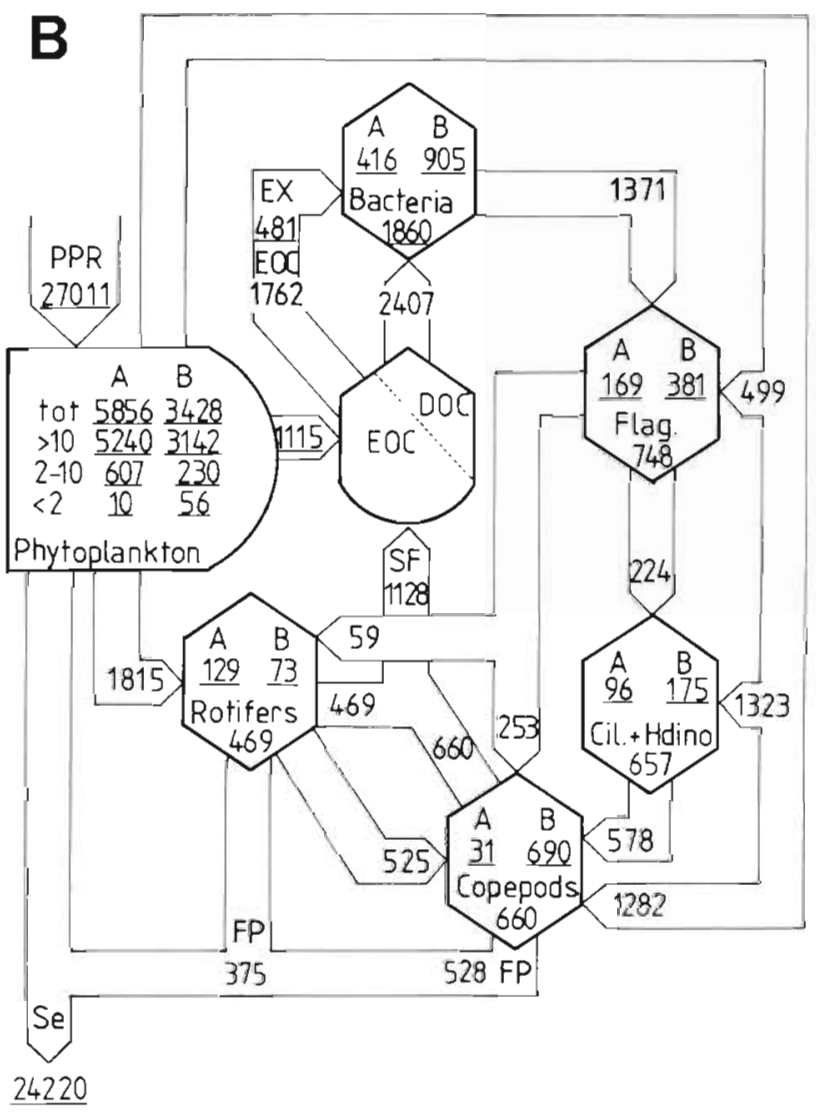

Fig. 4. Carbon flow diagrams (mg C $\mathrm{m}^{-2}$ ) for the growing phase (29 March to 5 May; Panel A) and the declining phase (5 May to 26 May; Panel Bj of the spring phytoplankton bloom in 1988 at Storgadden station. PPR = net primary production. Production of heterotrophic groups given under respective abbreviations. Flag., Cil and Hdino = heterotrophic nanoflagellates, ciliates and heterotrophic dinoflagellates, respectively. Se = sedimentation; $\mathrm{EX}=$ exudates immediately incorporated into bacterial carbon; DOC = dissolved organic carbon; $\mathrm{SF}=$ DOC released vid 'sloppy feeding' by metazooplankton (25\% of their total grazing); EOC $=$ combined pool of SF and dissolved exudates; FP = faecal pellets of metazooplankton ( $20 \%$ of their total grazing). Gross growth efficiency $40 \%$ for bacteria and protists $(50 \%$ for heterotrophic dinoflagellates), and $25 \%$ for metazooplankton. Biomass values: (Pane] A) $A^{*}=29$ March, $A=13$ April, B = 5 May; (Panel B) A = 5 May, B = 26 May. The phytoplankton biomass is divided into 3 size classes: $<2,2$ to 10 , and $>10 \mu \mathrm{m}$. Measured values are underlined 
The integral net bacterial production was $0.30 \mathrm{~g} \mathrm{C} \mathrm{m}^{-2}$, and $34 \%$ of it was channelled into bacterioplankton biomass (Fig. 4A). Bacteria obtained $43 \%$ of their carbon needs via immediate uptake of algal exudates (Fig. 4A). If their growth efficiency is assumed to be $40 \%$ (Lignell unpubl.), bacteria were able to satisfy almost all of the rest of their carbon demand with the organic carbon from the measured dissolved exudate and the estimated metazooplankton spillage pools (Fig. 4A).

\section{Declining phase}

During the declining phase of phytoplankton primary productivity (from 5 May to 26 May), the integral net primary production was $27.0 \mathrm{~g} \mathrm{C} \mathrm{m}^{-2}$, and at the same time, the phytoplankton standing stock decreased from 5.86 to $3.43 \mathrm{~g} \mathrm{C} \mathrm{m}^{-2}$. The biomass and activity of the heterotrophic compartments were many times as great as during the growing phase of the bloom, and total carbon demand of zooplankton was estimated to correspond to $29 \%$ of integral net primary production (Figs. 3B \& 48). The integral sedimentation value was $24.2 \mathrm{~g} \mathrm{C} \mathrm{m}^{-2}$.

The integral net bacterial production $\left(1.86 \mathrm{~g} \mathrm{C} \mathrm{m}^{-2}\right)$ was considerably greater than the observed increase in bacterial biomass (from 0.42 to $0.91 \mathrm{~g} \mathrm{C} \mathrm{m}^{-2}$ ), indicating strong grazing control of bacterioplankton (cf. Fig. 3B). In contrast to the observations made during the growing phase of the bloom, exudation and spillage of DOC by metazooplankton together satisfied only $48 \%$ of the bacterial carbon demand (Fig. 4B).

\section{Spring bloom carbon budget}

During the whole spring bloom period (from 29 March to 26 May), integral net primary production was $45.5 \mathrm{~g} \mathrm{C} \mathrm{m}^{-2}$ (Table 1), and net bacterial production in the euphotic layer amounted to $2.16 \mathrm{~g} \mathrm{C} \mathrm{m}^{-2}$, or $4.7 \%$ of the integral value. At the same time, the concentration of $\mathrm{NO}_{3}^{-}-\mathrm{N}$ in the whole water column decreased by $6.3 \mathrm{~g} \mathrm{~N} \mathrm{~m}^{-2}$, indicating that about $36 \mathrm{~g} \mathrm{C} \mathrm{m}^{-2}$ or $80 \%$ of the vernal primary production was 'new' [sensu Dugdale \& Goering (1967); under the favourable nutrient conditions in spring, algae were assumed to take up carbon and nitrogen in the Redfield ratio ( $\mathrm{C}: \mathrm{N}=5.7$ by weight)]. The proportion of new production agrees with that of $>75 \%$ found during spring blooms in the southern Baltic (Smetacek et al. 1984).

Sedimentation was by far the most important loss factor, corresponding to $72 \%$ of the integral net primary production (Table 1 ). When the sedimentation value of $72 \%$ is corrected for the estimated POC losses via settling of faecal pellets of metazooplankton
Table 1. Spring bloom carbon budget in the Tvärminne area in 1988. Major routes for net primary production (PPR): algal biomass increase, exudation, estimated zooplankton grazing on algae, and sedimentation. About $50 \%$ of exudates was taken up by bacterioplankton during $24 \mathrm{~h}{ }^{14} \mathrm{C}$ incubations Values in parentheses: total grazing on auto- and heterotrophs, and total sedimentation without correction for the estimated flux of the faecal pellets of metazooplankters

\begin{tabular}{|lcccc|}
\hline & \multicolumn{4}{c|}{ Carbon flow } \\
& $\left(\mathrm{g} \mathrm{C} \mathrm{m}^{-2}\right)$ & $(\%)$ PPR) \\
\hline Primary production & 45.5 & & \\
Algal biomass & 3.2 & 7.0 \\
Exudation & 1.7 & 3.7 \\
Heterotrophic nanoflagellates & 1.1 & $(2.6)$ & 2.4 & $(5.8)$ \\
Ciliates + heterotrophic & 1.5 & $(1.9)$ & 3.3 & $(4.1)$ \\
dinoflagellates & 2.2 & $(2.3)$ & 4.8 & $(5.0)$ \\
Rotifers & 1.3 & $(2.7)$ & 2.8 & $(6.0)$ \\
Copepods & $31.8(32.8)$ & $69.9(72.0)$ \\
Sedimentation & & & & \\
\hline
\end{tabular}

(Fig. 4), direct sedimentation losses from the phytoplankton community accounted for $70 \%$ of primary production. Recycling of metazooplankton faeces via coprohexy and coprophagy (Lampitt et al. 1990) evidently also took place in the euphotic layer, but since the overall contribution of faeces to sedimentation was small, this process was disregarded in the carbon budget (Fig. 4).

The total carbon consumption of zooplankton was $9.5 \mathrm{~g} \mathrm{C} \mathrm{m}^{-2}$, and $64 \%$ of this was accounted for by the direct consumption of phytoplankton standing stock (Table 1). During the ${ }^{14} \mathrm{C}$ incubations, about $2 \%$ of primary production was incorporated into bacteria via exudate uptake (Fig. 4), and grazing on algae by heterotrophic nanoflagellates was estimated to be about the same (Table 1). Thus, during the spring bloom the bacteria-heterotrophic nanoflagellates-ciliates and heterotrophic dinoflagellates 'microbial loop' processed directly about $3.5 \mathrm{~g} \mathrm{C} \mathrm{m}^{-2}$ of phytoplankton carbon. The sum of all direct losses of phytoplankton carbon (sedimentation, exudation and grazing by zooplankton), corrected for the increase in algal biomass, was about $94 \%$ of the integral net primary production (Table 1).

\section{DISCUSSION}

\section{Fate of the spring phytoplankton bloom}

\section{Zooplankton grazing}

Our estimate for the total carbon consumption of copepods and rotifers ( $11 \%$ of the integral vernal net primary production; Table 1) supports the general view 
of the small importance of metazooplankton grazing in controlling the spring phytoplankton bloom in the Baltic (Forsskåhl et al. 1982, Peinert et al. 1982, Kuparinen et al. 1984, Larsson et al. 1986). Moreover, the total carbon consumption by copepods $(6 \%$ of net primary production) falls within the range of 1 to $9 \%$ reported for nearby coastal and shelf-sea areas, including the North Sea (Nielsen \& Richardson 1989), the Danish Straits (Nicolajsen et al. 1983), and a Norwegian fjord (Lännergren \& Skjoldal 1976).

Our estimates of the carbon flow from the autotrophic to the heterotrophic community and within the latter community (Fig. 4) were based on the scenario emerging from the literature about predator-prey interactions in pelagic plankton communities. During the growing phase of the spring bloom, Acartia spp. nauplii predominated in the copepod community, and hence predation by copepods on the dominant rotifer Synchaeta littoralis was probably small (Stoecker \& Egloff 1987). Accordingly, due to the lack of predation from 'above' the production of rotifers was estimated based on the corresponding biomass increase.

In addition, it was assumed that the bacterial net production in excess of the portion channelled into bacterial biomass increase was chiefly consumed by heterotrophic nanoflagellates (Fenchel 1984). Nanoflagellates were then grazed by ciliates, heterotrophic dinoflagellates and metazooplankters (Andersen \& Sørensen 1986, Stoecker \& Egloff 1987, Egloff 1988). On the other hand, grazing by Synchaeta littoralis on ciliates was probably small (cf. Egloff 1988). The relative importance of ciliates and metazooplankters in the grazing of heterotrophic nanoflagellates was assessed from the corresponding biomass distribution and clearance rates of $10^{4}$ body volumes $\mathrm{h}^{-1}$ for ciliates (Fenchel 1980), $2.5 \times 10^{3}$ body volumes $h^{-1}$ for adult metazooplankters and $5 \times 10^{3}$ body volumes $\mathrm{h}^{-1}$ for naupliar copepodites (Uitto unpubl.).

During the declining phase of the bloom, the temporal course of the biomass in all compartments in the heterotrophic community (except copepods) showed clear predator-prey relationships (Fig. 3B). The copepod community was dominated by adult Acartia spp. females, and hence both protists and rotifers were assumed to be controlled by copepods (Peinert et al. 1982, Stoecker \& Egloff 1987, Egloff 1988). During the entire spring, the zooplankters were assumed to satisfy their residual carbon demands from the phytoplankton standing stock (Heinbokel 1978, Smetacek 1981, Stoecker \& Egloff 1987).

The total carbon consumption of copepods was estimated from their biomass increase during the ice-free period, as predation on copepods is probably a minor factor during the entire spring in the northern Baltic (Rudstam 1988). This also seems to be justified by the temporal course of the copepod biomass (Fig. 3B; the steep increase during the latter half of the bloom was abruptly ended by upwelling after 26 May).

Gross growth efficiencies ranging from $\leq 10 \%$ to $40 \%$ have been reported for copepods (Williams \& Lindley 1980, Conover \& Mayzaud 1984, Sheldon et al. 1986) and for rotifers (Scott 1980), which were the most important metazooplankton groups during our study. We used the constant value of $25 \%$ adopted by Cole et al. (1988), but even with a metazooplankton growth efficiency of $10 \%$, the total direct grazing on algae (the summed grazing by protists and metazooplankters) would have accounted for only $30 \%$ of the integral net primary production (cf. Table 1 ).

For comparison, metazooplankton grazing was estimated using 2 linear regression equations (for prey diameters 2 to $10 \mu \mathrm{m}$ and $>10 \mu \mathrm{m})$. The equations are based on experiments made in summer 1988, and they estimate metazooplankton clearance rates from the biomasses of the predominant taxa (copepods, cladocerans, rotifers and planktonic larvae; Uitto unpubl.). When the vernal phytoplankton biomass values were corrected for inedible (too large) algae, the estimated metazooplankton grazing in spring 1988 was $10.9 \mathrm{~g} \mathrm{C}$ $\mathrm{m}^{-2}$, or $24 \%$ of primary production. This supports the view that the metazooplankton is of little quantitative importance in controlling the phytoplankton spring bloom in our study area. Moreover, when account is taken of the temperature difference of 10 to $15^{\circ} \mathrm{C}$ between the spring and summer periods in the area and a $Q_{10}$ value of about 3 is assumed for the metazooplankton feeding rates (e.g. Muck \& Lampert 1984), the grazing value obtained with the regression equations is consistent with that obtained in the present study (Table 1).

On average, the biomass of ciliates was about $150 \%$ greater than that of heterotrophic dinoflagellates, and thus ciliates along with heterotrophic nanoflagellates were evidently the main algal grazers among the protists (Table 1, Fig. 4). Unlike the copepods, the protists were clearly controlled from above by grazing (Fig. 3B), and thus the production of the ciliate assemblage was estimated on the basis of size-specific growth rates (Finlay 1977) instead of changes in the biomass. When corrected for temperature, the estimated generation time of ciliates averaged $0.8 \mathrm{~d}$, which is within the range of 0.5 to $1.7 \mathrm{~d}$ reported by Heinbokel $(1978,1988)$. The growth rate estimates for heterotrophic nanoflagellates and dinoflagellates were based on their maximum weekly biomass increase, but due to continuous grazing pressure they were probably underestimates.

Detailed reports of vernal planktonic carbon budgets, which include a simultaneous estimation of the algae-metazooplankton grazing chain, the bacteria- 
heterotrophic nanoflagellates - ciliates microbial loop, and sedimentation as alternative routes of phytoplankton carbon, are still scarce or lacking in the Baltic, and in other boreal coastal and shelf-sea areas as well. For example, the estimated carbon consumption of zooplankton has usually been assumed to be solely accounted for by phytoplankton primary production. The total carbon demand of the protists and metazooplankton in the present study was $9.5 \mathrm{~g} \mathrm{C} \mathrm{m}^{-2}$, and according to our calculations based on the reported predator-prey relationships (see above) the predatory processes within the heterotrophic community accounted for $36 \%$ of this value (Table 1, Fig. 4).

\section{Sedimentation}

The integral sedimentation value for the whole spring bloom period accounted for $72 \%$ of the primary production (Table 1). This value seems high when compared with the results of other studies carried out in the Baltic, in which the corresponding proportion has been found to vary between 30 and $65 \%$ (Forsskåhl et al. 1982, Peinert et al. 1982, Kuparinen et al. 1984, Larsson et al. 1986, Leppänen 1988). However, most of the sedimentation estimates cited above were based on unpreserved samples (Forsskảhl et al. 1982, Kuparinen et al. 1984, Larsson et al. 1986, Leppänen 1988), which were susceptible to microbial degradation in the sediment traps. Peinert et al. (1982) used chloroform preservation in their sediment traps, but small chloroform additions have subsequently been found to be ineffective in inhibiting bacterial activity (Gundersen \& Wassmann 1990).

In the present study formalin preservation was used in the sediment traps, as formalin has proved to be an effective inhibitor of microbial decomposition of settled material (Knauer et al. 1984). However, this resulted in a very high integral sedimentation value of $84 \%$ of primary production. When sedimentation was measured without preservation of the settled material, the integral value (58\% of the primary production) was in the upper end of the range reported in the earlier studies.

The methodological problems in sedimentation studies are still not adequately understood (see Gundersen \& Wassmann 1990). Traps without preservation underestimate sedimentation due to leaching of dissolved organics, to microbial degradation of settled material and to 'swimmers' entering, grazing and then leaving the traps. On the other hand, traps with preservation may overestimate the amount of settling material due to being entered by actively swimming organisms (phytoplankton, and zooplankton and other animals).
During the present study, clearly larger amounts of Peridiniella catenata cells were found by microscopy in traps with than without formalin preservation. Vertical migration of $P$. catenata, extending as deep as $30 \mathrm{~m}$, has been observed during a spring bloom in the Baltic proper (Passow 1991a). Thus, the 'excess' amounts of $P$. catenata carbon in traps with formalin preservation, which accounted for between 2 and 24 percentage points of the difference in POC gain between the traps with and without preservation, were subtracted from the total sedimentation values obtained with preservation.

If the mineralization rate of $\mathrm{POC}$ in traps without formalin preservation is assumed to be $5 \% \mathrm{~d}^{-1}$ (Iturriaga 1979), the corrected integral sedimentation value for these traps accounts for $70 \%$ of the vernal primary production. This value agrees well with that of $72 \%$ obtained with formalin preservation and corrected for the 'excess' Peridiniella catenata carbon.

Resuspension of material from the benthos and surrounding shallows probably increased the sedimentation values at a depth of $30 \mathrm{~m}$. However, between 30 April and 18 May, when the highest sedimentation rates were recorded, the wind and current velocities in the area varied from low to moderate (J. Haapala pers. comm.). Moreover, both the $\mathrm{C}: \mathrm{N}$ and the $\mathrm{C}$ : chlorophyll a ratios of the settled material were low during the spring bloom (Heiskanen \& Gundersen unpubl.), indicating that the deposits were of fresh phytodetrital origin. Thus, the contribution of resuspended material to the vernal sedimentation value was probably low.

\section{Exudation and the role of bacteria and viruses}

Exudation was $3.7 \%$ of the vernal primary production (Table 1), supporting earlier findings of the minor role of this loss route during spring off the SW coast of Finland (Lignell 1990). The dissolved exudates were mainly small compounds of a few hundred daltons (Lignell unpubl.), and hence bacteria probably preferred them as substrate (Lancelot 1984). Thus, during the whole spring period bacteria were able to satisfy $54 \%$ of their total carbon demand with exudates and DOC spillage by metazooplankton [bacterial growth efficiency $40 \%$ (Lignell unpubl.); Fig. 4]. The amount of bacterial organic carbon needs not accounted for by these processes corresponded to about $5 \%$ of integral net primary production (see Fig. 4, Table 1). A part of this cap was probably fulfilled by DOC diffusing out of faecal pellets (cf. Jumars et al. 1989). This process was not taken separately into account in our carbon budget (Fig. 4), however, since it was at least in part included in the DOC excretion value of metazooplankton (25\% of the total carbon ingested) found by Copping \& 
Lorenzen (1980) by using ${ }^{14} \mathrm{C}$-labelled phytoplankton and $48 \mathrm{~h}$ incubation times. On the other hand, the cap between carbon requirements of bacteria and calculated available DOC does not necessarily challenge the balance in our carbon budget calculations (Table 1), since organic carbon is effectively recycled in the planktonic food web. Thus, the carbon needs of the heterotrophic compartments may exceed the input by phytoplankton primary production (Elmgren 1984). Moreover, occasional inflows rich in allochthonous organic carbon from the inner archipelago provide an alternative source of carbon for bacteria in the Tvärminne area (cf. Niemi 1975).

The role of viruses in aquatic ecosystems is at present under re-evaluation, as they seem to be abundant $\left(10^{6}\right.$ to $\left.10^{9} \mathrm{ml}^{-1}\right)$ and active and hence potentially control both auto- and heterotrophic plankton communities (Bratbak et al. 1990, Suttle et al. 1990). However, even though viruses may have modified the species composition of the algal community during our study (cf. Suttle et al. 1990), the difference of $<6 \%$ between the primary production and the estimated channelling or phytoplankton carbon (Table 1) suggests that viral infection and subsequent lysis of phytoplankton cells were quantitatively of small importance. Otherwise, one would have expected an increased release of DOC from infected algal cells, causing diminished sedimentation and hence a considerable apparent surplus of organic carbon inputs in our budget.

\section{Uncertainty in the carbon budget}

There were 2 potentially serious sources of error in our carbon budget. First, there is usually a basic difference between the primary productivity and sedimentation records: the former are obtained from measurements made at a single point in time, whereas the sedimentation traps continuously collect information on sedimentation between 2 sampling dates. Thus a productivity peak may have been missed due to insufficient sampling frequency. Moreover, the prevailing western currents of 1 to $2 \mathrm{~cm} \mathrm{~s}^{-1}$ (J. Haapala pers. comm.) negate any direct spatial relationship between the production and sedimentation measurements in our study area.

Wulff (1979) showed in the northern Baltic, however, that weekly sampling during the spring bloom period (used also in the present study) along with a sampling interval of 2 wk during the rest of the growth season allows detection of changes in primary production between years that are greater than 10\%. Moreover, Passow (1991b) found that during a spring bloom the sinking rates of dominant algae ranged from 15 to $70 \mathrm{~m} \mathrm{~d}^{-1}$ in the central Baltic. This suggests that the maximal horizontal transport of the algal cells settling in our sediment traps was about $3.5 \mathrm{~km}$ (horizontal current velocity 1 to $2 \mathrm{~cm} \mathrm{~s}^{-1}$, depth of traps $30 \mathrm{~m}$ ). Thus, our integral net primary production and sedimentation values should fit reasonably well both temporally and spatially

Another major problem concerns the reliability of our sampling procedure. The production of protists (except ciliates) and metazooplankters was estimated from the corresponding maximal or overall biomass increase (see above), with the implicit assumption that the same water mass was sampled throughout the study. This was evidently not true due to the prevailing horizontal currents, which transformed our sampling interval of $1 \mathrm{wk}$ to a distance of about 6 to $12 \mathrm{~km}$. In the spring, plankton organisms in the Baltic show considerable horizontal patchiness, caused by mesoscale eddies and localized bloom dynamics (Kahru \& Nömmann 1990). Moreover, the combined effect of currents and active vertical migration of plankters has also been shown to result in vertically patchy distribution of both zooplankton (see Longhurst 1981) and motile Peridiniella catenata cells (Passow 1991a).

However, our estimates of the carbon consumption of ciliates were based on their size-specific growth rates (Finlay 1977), while the biomass-specific clearance rates of metazooplankters (Uitto unpubl.) gave grazing values similar to those based on their biomass increase (see above). Ciliates and metazooplankters accounted for the major part of the grazing on algae (Table 1), hence suggesting that our grazing estimates were of the right magnitude. Moreover, our detailed carbon budget for the spring bloom balanced well, as the sum of the algal biomass increase and the independently measured loss factors (exudation, grazing and sedimentation) deviated less than $6 \%$ from the integral net primary production (Table 1). This provides further support for our conclusion that the heterotrophic processes in the vernal planktonic food web were of small quantitative importance in our study area in 1988.

\section{General and specific characteristics of the spring bloom in the Tvärminne area in $\mathbf{1 9 8 8}$}

The phytoplankton spring bloom started in early April and continued to increase strongly at the beginning of May, after a lag caused by upwelling (Figs. 2A \& 3A). The bloom started well before the onset of thermal stratification in the middle of May (Fig. 2B), which suggests that these 2 phenomena were not connected. On the other hand, a vertical salinity gradient was formed in the upper $10 \mathrm{~m}$ layer in early April as a consequence of melting ice and inflowing freshwater 
(cf. Niemi 1975), and this density gradient evidently provided the temporary stability necessary for the initiation of the spring bloom (Kahru \& Nömmann 1990, Smetacek \& Passow 1990). Then the upper water layer became virtually homogeneous until the end of April (Fig. 2). The critical depth for primary production $\left(Z_{c r i t}\right.$ allowing phytoplankton growth) was estimated for this period, using the formula (Tett \& Edwards 1984)

$$
Z_{\text {crit }}=\alpha \times I_{0} /\left(K \times R_{B}\right)
$$

where $\alpha=$ photosynthetic efficiency (initial slope of biomass-specific photosynthesis per irradiance), $I_{0}=$ mean diel irradiance immediately below the surface, $K=$ attenuation coefficient of light (ca $0.4 \mathrm{~m}^{-1}$ ), and $R_{\mathrm{B}}=$ biomass-specific respiration of phytoplankton (assumed to equal 10\% of maximum biomass-specific photosynthesis; see Smetacek \& Passow 1990).

In April, $Z_{\text {cril }}$ decreased from 180 to $68 \mathrm{~m}$, hence being considerably deeper than the $46 \mathrm{~m}$ deep Storgadden Station. This result is in accordance with our finding that the homogeneity of the upper water layer did not prevent the development of the bloom in April (Fig. 3A). Moreover, on 28 April a slight vertical salinity gradient was formed with an increase of $0.04 \%$ from the surface to $5 \mathrm{~m}$ depth, which probably facilitated the development of the bloom (Fig. 3A). Gradients of this type frequently form under the estuarine conditions prevailing in the Baltic, and a salinity difference of 0.02 to $0.1 \%$ can be sufficient to suppress local vertical mixing (Kahru \& Nömmann 1990).

During the growing and peak phases of the spring bloom in 1988, the phytoplankton community consisted predominantly of the dinoflagellates Peridiniella catenata and Gymnodinium sp., which accounted for about $80 \%$ of the algal biomass. During the declining phase of the bloom, the diatom Skeletonema costatum became abundant, which is typical in late spring in our study area. Thus, the vernal phytoplankton succession was the opposite to that in the southern Baltic, where a peak of diatoms invariably precedes that of dinoflagellates (Smetacek et al. 1984). The succession differed from that in other boreal coastal and shelf-sea areas also, where the vernal blooms seem generally to be dominated by diatoms, rather than by dinoflagellates (Colebrook 1984; see also Wassmann 1991).

Off the SW coast of Finland, vernal blooms may be dominated by either dinoflagellates or diatoms, or both (e.g. Niemi 1975, Forsskåhl et al. 1982, Lignell 1990). The factors determining the dominant species are at the moment unclear. It is of special importance for the vernal planktonic food webs in our study area, however, that the phytoplankton communities frequently consist predominantly of the large, chain-forming dinoflagellate Peridiniella catenata, this pattern being enhanced by the low diversity of phytoplankton in the low-salinity waters off the SW coast of Finiand. In contrast to many of the small vernal algal forms which predominate in the southern Baltic (Peinert et al. 1982) and in other boreal areas (Colebrook 1984), this alga, with a chain length of several hundred $\mu \mathrm{m}$, is evidently inedible even for adult crustaceans. Moreover, the losses via autolysis can also be expected to be minor, when these heavy chains settle from the mixed layer during the collapse of the bloom. This may in part explain our high sedimentation value of $72 \%$ of primary production compared to those of 15 to $65 \%$ found in other boreal coastal and shelf-sea areas (for a review see Wassmann 1991).

In previous studies, about $40 \%$ of the vernal primary production has been reported to settle out from the mixed layer in our study area (Forsskåhl et al. 1982, Kuparinen et al. 1984). These values are considerably lower than that of $72 \%$ found in the present study. In contrast to our results, the earlier studies showed a major surplus of ca $50 \%$ of integral primary production compared to the sum of algal biomass increase and loss factors (grazing by metazooplankton and sedimentation), which suggests either that a considerable part of the primary production remained in the mixed layer as dead DOC and POC, or that the losses (especially sedimentation, the main loss factor) were underestimated. In contrast to our measurement procedure, no preservation of the settled material was used in the sediment traps employed by Forsskăhl et al. (1982) and Kuparinen et al. (1984), which probably led to underestimation of settled POC as a consequence of mineralization processes (Iturriaga 1979, Gundersen \& Wassmann 1990).

Our sedimentation value obtained without preservation of the settled POC ( $58 \%$ of primary production) was similar to the corresponding value of $60 \%$ of particulate primary production found by Leppänen (1988) for a spring bloom in the northern Baltic proper. On the other hand, this sedimentation value was clearly higher than those reported by Forsskåhl et al. (1982) and Kuparinen et al. (1984), possibly reflecting differences in the methodology or in the fate of different vernal phytoplankton communities. Moreover, as discussed above, account must be taken of the general problems of combining measurements made on different spatial and temporal scales and of the prevailing plankton patchiness.

Zooplankton grazing is potentially important in restoring a part of the nutrients incorporated in phytoplankton, as these would otherwise be lost from the upper water layer along with the settling phytoplankton. Proto- and metazooplankton grazing on algae corresponded to about $12 \%$ of the primary production in spring 1988 (when corrected for the estimated loss of $20 \%$ of metazooplankton grazing as faecal pellets; 
cf. Table 1), and the vernal bloom has been found to account for 37 to $58 \%$ of the annual phytoplankton production in the Tvärminne area (Kuparinen 1984, Kuosa \& Kivi 1989, Lignell 1990). If we disregard the input of new nutrients from below the nutricline and from the atmosphere, and assume that zooplankton grazing is the only process retaining the limiting nutrient in the mixed layer in spring, these values would imply that the nutrients were recycled at least 6 times [42 percentage points $/(0.12 \times 58$ percentage points)] during the rest of the productive season.

\section{Concluding remarks}

During the whole spring bloom period, about $6 \%$ of the integral net primary production was either exuded directly or released as metazooplankton DOC spillage, hence fuelling the microbial loop (Fig. 4). In addition, about $6 \%$ of the primary production was processed directly by protozooplankton (Table 1). Nielsen \& Richardson (1989) likewise found that the importance of the microbial loop was small during a spring bloom in the North Sea. The minor role of this route of phytoplankton carbon during vernal blooms indicates that there are fundamental differences in the functioning of the ecosystem between the spring and summer periods, as during the latter period a considerable increase in the importance of the microbial loop can be expected in boreal waters (Azam et al. 1983, Kuosa \& Kivi 1989, Nielsen \& Richardson 1989, Lignell 1990). In the Bering and Chukchi seas, Andersen (1988) found that about $5 \%$ of the primary production was processed by the microbial loop in the nutrient-rich frontal zone, where large diatoms predominated, whereas at the same time the corresponding value was 70 to $80 \%$ in the more oligotrophic parts of the area, where nano- and picoplanktonic algae predominated. Thus, the variations in the importance of the microbial loop seem to be primarily related to the size-structure of the prevailing phytoplankton community, which again is determined by the nutritional stage and stability of the system: large algal forms usually predominate when nutrients are abundant and turbulence is high (spring), while small ones are predominant during periods of mutrient scarcity and low turbulence (summer) (Margalef 1978, Thingstad \& Sakshaug 1990).

The carbon flow model presented here is based on the 'grazing food chain' and 'microbial loop' as alternative routes for phytoplankton primary production (Azam et al. 1983). The model assumes that the grazers preferably consume organisms which are about an order of magnitude smaller than themselves. Empirical data seem to justify this assumption (Sheldon et al.
1972; see also the discussion on predator-prey relationships above). However, it is evident that our model is an oversimplification of the natural food web, as microorganisms are not merely controlled 'vertically' (i.e. from 'above' by predators and from 'below' by nutrients or prey; Pomeroy \& Wiebe 1988, Thingstad \& Sakshaug 1990). For example, Smetacek (1981) showed that non-loricate ciliates, which constituted a large part of the protozooplankton during the present study, frequently ingest cells of a size comparable to or larger than their own. Accordingly, Pomeroy \& Wiebe (1988) concluded that since microorganisms may operate on several trophic levels simultaneously, the reality of the use of ecological efficiency calculations in ecosystem models is questionable.

We acknowledge this drawback in the case of our tentative model as well. However, during the spring bloom the planktonic food web is considerably simplified due to the predominance of large and chained algal forms, which limits the importance of the carbon flow processed by pico-, nano- and micro-sized compartments. Thus, our main conclusion, that the fate of the spring phytoplankton bloom in the Tvärminne area is sedimentation out of the mixed layer, remains unchallenged.

Acknowledgements. J. Haapala provided vital hydrographic information, and $\mathrm{J}$. Kuparinen helped to compile the biological data. We are grateful to T. F. Thingstad for his valuable comments on the manuscript. In addition, the manuscript benefited considerably from the comments of 3 anonymous referees. The linguistic form was checked by Mrs A. Damstrom. The study is a contribution of the project PELAG, and it was financed by the Academy of Finland and the Maj and Tor Nessling foundation.

\section{LITERATURE CITED}

Amblard, C. (1988). Seasonal succession and strategies of phytoplankton development in two lakes of different trophic states. J. Plankton Res. 10: 1189-1208

Andersen, P. (1988). The quantitative importance of the 'microbial loop' in the marine pelagic: a case study from the North Bering/Chukchi seas. Arch. Hydrobiol. Beih. Ergebn. Limnol 31: 243-251.

Andersen, P.. Sørensen, H. M. (1986). Population dynamics and trophic coupling in pelagic microorganisms in eutrophic coastal waters. Mar. Ecol. Prog. Ser. 33: 99-109

Azam, F., Fenchel, T., Field, J. G., Gray, J. S., Meyer-Reil, L. A., Thingstad, F. (1983). The ecological role of watercolumn microbes in the sea. Mar Ecol. Prog. Ser. 10: $257-263$

Bathmann, U. V., Noji, T T., von Bodungen, B. (1990). Copepod grazing potential in late winter in the Norwegian Sea - a factor in the control of spring phytoplankton growth? Mar. Ecol. Prog. Ser. 60: 225-233

Børsheim, K. Y., Bratbak, G. (1987). Cell volume to cell carbon conversion factors for a bacterivorous Monas sp. enriched from seawater. Mar. Ecol. Prog. Ser. 36: 171-175 
Bratbak, G., Heldal, M., Norland, S., Thingstad, T F. (1990) Viruses as partners in spring bloom microbial trophodynamics. Appl. environ. Microbiol. 56: 1400-1405

Cole, J. J., Findlay, S., Pace, M. L. (1988). Bacterial production in fresh and saltwater ecosystems: a cross-system overview. Mar. Ecol. Prog. Ser. 43: 1-10

Colebrook, J. M. (1984). Continuous plankton records: relationships between species of phytoplankton and zooplankton in the seasonal cycle. Mar. Biol. 83: 313-323

Conover, R. J., Mayzaud, P. (1984). Utilization of phytoplankton by zooplankton during the spring bloom in a Nova Scotia inlet. Can. J. Fish. Aquat. Sci. 41: 232-244

Copping, A. E., Lorenzen, C. J. (1980). Carbon budget of a marine phytoplankton-herbivore system with carbon-14 as tracer. Limnol. Oceanogr. 25: 873-882

Davis, P. G., Sieburth, J. McN. (1982). Differentiation of phototrophic and heterotrophic nanoplankton populations in marine waters by epifluorescence microscopy. Annls Inst. océanogr., Monaco 58 (suppl.): 249-260

Dugdale, R. C., Goering, J. J. (1967). Uptake of new and regenerated forms of nitrogen in primary productivity. Limnol. Oceanogr. 12: 196-206

Edler, L., Hällfors, G., Niemi, $\AA$. (1984). A preliminary checklist of the phytoplankton of the Baltic Sea. Acta bot. Fenn 128: $1-26$

Egloff, D. A. (1988). Food and growth relations of the marine microzooplankter, Synchaeta cecilia (Rotifera). Hydro. biologia 157: 129-141

Elmgren, R. (1984). Trophic dynamics in the enclosed, brackish Baltic Sea. Rapp. P.-v. Réun. Cons. int. Explor Mer 183: 152-169

Fenchel, T (1980). Suspension feeding in ciliated protozoa: functional response and particle size selection. Microb. Ecol. 6: 1-11

Fenchel, T. (1982). Ecology of heterotrophic microflagellates Il. Bioenergetics and growth. Mar. Ecol. Prog. Ser. 8: $225-231$

Fenchel, $T$ (1984). Suspended marine bacteria as a food source. In: Fasham, M. J. R. (ed.) Flows of energy and materials in marine ecosystems. Plenum, New York and London, p. 301-315

Finlay, B. J. (1977). The dependence of reproductive rate on cell size and temperature in freshwater ciliated protozoa. Oecologia 30: 75-81

Forsskåhl, M., Laakkonen, A., Leppänen, J.-M., Niemi, Å., Sundberg, A., Tamelander, G. (1982). Seasonal cycle of production and sedimentation of organic matter at the entrance to the Gulf of Finland. Neth. J. Sea Res. 16: 290-299

Fuhrman, J., Azam, F. (1982). Thymidine incorporation as a measure of bacterioplankton production in marine surface waters: evaluation and field results. Mar. Biol. 66: 109-120

Goldman, J. C., Dennett, M. R., Gordin, H. (1989). Dynamics of herbivorous grazing by the heterotrophic dinoflagellate Oxyrrhis marina. J. Plankton Res. 11: 391-407

Gundersen, K., Wassmann, P. (1990). Use of chloroform in sediment traps: caution advised. Mar. Ecol. Prog. Ser, 64: $187-195$

Haas, L. W. (1982). Improved epifluorescence microscopy for observing planktonic micro-organisms. Annls Inst. océanogr., Monaco 58 (suppl.): 261-266

Heinbokel, J. F. (1978). Studies on the functional role of tintinnids in the Southern California Bight. I. Grazing and growth rates in laboratory cultures. Mar. Biol. 47: $177-189$

Heinbokel, J. F. (1988). Reproductive rates and periodicities of oceanic tintinnine ciliates. Mar. Ecol. Prog. Ser. 47: $239-248$
Hobbie, J. E., Daley, R. J., Jasper, S. (1977). Use of Nuclepore filters for counting bacteria by epifluorescence microscopy. Appl. environ. Microbiol. 33: 1225-1228

Iturriaga, R. (1979). Bacterial activity related to sedimenting particulate matter. Mar. Biol. 55: $157-169$

Jumars, P. A., Penry, D. L., Baross, J. A., Perry, M. J., Frost, B. W. (1989). Closing the microbial loop: dissolved carbon pathway to heterotrophic bacteria from incomplete ingestion, digestion and absorption in animals. Deep Sea Res. 36: 483-495

Kahru, M., Nömmann, S. (1990). The phytoplankton spring bloom in the Baltic Sea in 1985, 1986: multitude of spatiotemporal scales. Contin. Shelf Res. 10: 329-354

Kivi, K. (1986). Annual succession of pelagic protozoans and rotifers in the Tvärminne Storfjärden, SW coast of Finland Ophelia Suppl. 4: 101-110

Knauer, G. A., Karl, D. M., Martin, J. H., Hunter, C. N. (1984). In situ effects of selected preservatives on total carbon and metals collected in sediment traps. J. mar. Res. 42: 445-462

Kuosa, H., Kivi, K. (1989). Bacteria and heterotrophic flagellates in the pelagic carbon cycle in the northern Baltic Sea. Mar. Ecol. Prog. Ser. 53: 93-100

Kuparinen, J. (1984). Annual and seasonal fluctuation of primary productivity and overall respiration in a pelagic plankton community off Tvärminne, SW coast of Finland Ophelia Suppl. 3: 111-122

Kuparinen, J. (1988). Development of bacterioplankton during winter and early spring at the entrance to the Gulf of Finland, Baltic Sea. Verh. int. Verein. Limnol. 23 $1869-1878$

Kuparinen, J., Leppänen, J.-M., Sarvala, J., Sundberg, A., Virtanen, A. (1984). Production and utilization of organic matter in a Baltic ecosystem off Tvärminne, southwest coast of Finland. Rapp. P.-v. Réun. Cons. int. Explor. Mer 183: $180-192$

Kuuppo-Leinikki, P., Kuosa, H. (1989). Preservation of picoplanktonic cyanobacteria and heterotrophic nanoflagellates for epifluorescence microscopy. Arch. Hydrobiol. 114: $431-436$

Lampitt, R. S., Noji, T., von Bodungen, B. (1990). What happens to zooplankton faecal pellets? Implications for material flux. Mar. Biol. 104: 15-23

Lancelot, C. (1984). Extracellular release of small and large molecules by phytoplankton in the southern bight of the North Sea. Estuar. coast. Shelf Sci. 18: 65-77

Lännergren, C., Skjoldal, H. R. (1976). The spring phytoplankton bloom in Lindáspollene, a land-locked Norwegian fjord. In: Persoone, G., Jaspers, E. (eds.) Proceedings of the 10th European Marine Biology Symposium, Vol. 2. Universal Press, Wetteren, p. 363-391

Larsson, U., Hobro, R., Wulff, F. (1986). Dynamics of a phytoplankton spring bloom in a coastal area of the Northern Baltic proper. Contr. Askö Lab., Univ. Stockholm 30: 1-32

Laws, E. A., Bienfang, P. K., Ziemann, D. A., Conquest, L. D. (1988). Phytoplankton population dynamics and the fate of production during spring bloom in Auke Bay, Alaska. Limnol. Oceanogr. 33: 57-65

Leppänen, J.-M. (1988). Cycling of organic matter during the vernal growth period in the open northern Baltic proper. Ph.D. thesis. Finn. mar. Res. 255

Levasseur, M., Therriault, J.-C., Legendre, L. (1984). Hierarchical control of phytoplankton succession by physical factors. Mar. Ecol. Prog. Ser. 19: 211-222

Lignell, R. (1990). Excretion of organic carbon by phytoplankton: its relation to algal biomass, primary productivity and bacterial secondary productivity in the Baltic Sea. Mar. Ecol. Prog. Ser. 68: 85-99 
Lignell, R., Kaitala, S., Kuosa, H. (1992). Factors controlling phyto- and bacterioplankton in late spring on a salinity gradient in the northern Baltic. Mar. Ecol. Prog. Ser. 84: $121-131$

Longhurst, A. R. (1981). Significance of spatial variability. In: Longhurst, A. R. (ed.) Analysis of marine ecosystems. Academic Press, New York, p. 415-441

Margalef, R. (1978). Life-forms of phytoplankton as survival alternatives in an unstable environment. Oceanol. Acta 1: 493-510

Muck, P., Lampert, W. (1984). An experimental study on the importance of food conditions for the relative abundance of calanoid copepods and cladocerans 1. Comparative feeding studies with Eudiaptomus gracilis and Daphnia longispina. Arch. Hydrobiol. Suppl. 66: $157-179$

Mullin, M. M. (1969). Production of zooplankton in the ocean: the present status and problems. Oceanogr. mar. Biol. A. Rev. 7: 293-314

Nicolajsen, H., Mohlenberg, F., Kiørboe, T. (1983). Algal grazing by the planktonic copepods Centropages hamatus and Pseudocalanus sp: diurnal and seasonal variation during the spring phytoplankton bloom in the Oresund. Ophelia 22: 15-31

Nielsen, T. G., Richardson, K. (1989). Food chain structure of the North Sea plankton communities: seasonal variations of the role of the microbial loop. Mar. Ecol. Prog. Ser. 56: $75-87$

Niemi, $\AA$. (1975). Ecology of phytoplankton in the Tvärminne area, SW coast of Finland. II. Primary production and environmental conditions in the archipelago and the sea zone. Acta bot. Fenn. 105: 1-73

Niemi, M., Kuparinen, J., Uusi-Rauva, A., Korhonen, K. (1983) Preparation of algal samples for liquid scintillation counting. Hydrobiologia 106: 149-156

Passow, U. (1991a). Vertical migration of Gonyaulax catenata and Mesodinium rubrum. Mar. Biol. 110: 455-463

Passow, U. (1991b). Species-specific sedimentation and sinking velocities of diatoms. Mar. Biol. 108: 449-455

Peinert, R., Saure, A., Stegmann, P., Stienen, C., Haardt, $H_{\text {, }}$ Smetacek, V. (1982). Dynamics of primary production and sedimentation in a coastal ecosystem. Neth. J. Sea Res. 16: 276-289

Peters, R. H., Downing, J. A. (1984). Empirical analysis of zooplankton filtering and feeding rates. Limnol. Oceanogr. 29: $763-784$

Pomeroy, L. R., Wiebe, W. J. (1988). Energetics of microbial food webs. Hydrobiologia 159: 7-18

Riemann, B., Bjørnsen, P. K., Newell, S., Fallon, R. (1987). Calculation of cell production of coastal bacteria based on measured incorporation of ${ }^{3} \mathrm{H}$-thymidine. Limnol. Oceanogr. 32: $471-476$

Rudstam, L. G. (1988). Patterns of zooplanktivory in a coastal

This article was presented by H. R. Skjoldal, Bergen, Norway area of the northern Baltic proper. Ph.D. thesis, Dept of Zoology, Askö Laboratory, Univ. of Stockholm

Scott, J. M. (1980). Effect of growth rate of the food algae on the growth/ingestion efficiency of a marine herbivore. J. mar. biol. Ass. U.K. 60: 681-702

Sheldon, R. W., Nival, P., Rassaoulzadegan, F. (1986). An experimental investigation of a flagellate-ciliate-copepod food chain with some observations relevant to the linear biomass hypothesis. Limnol. Oceanogr. 31: 184-188

Sheldon, R. W., Prakash, A., Sutcliffe, W. H. (1972). The size distribution of particles in the ocean. Limnol. Oceanogr. 17: $327-340$

Smetacek, V. (1981). The annual cycle of protozooplankton in the Kiel Bight. Mar. Biol. 63: 1-11

Smetacek, V., Passow, U. (1990). Spring bloom initiation and Sverdrup's critical-depth model. Limnol. Oceanogr. 35: $228-234$

Smetacek, V., von Bodungen, B., Knoppers, B., Peinert, R., Pollehne, F., Stegmann, P., Zeitschel, B. (1984). Seasonal stages characterizing the annual cycle of an inshore pelagic system. Rapp. P.-v. Réun. Cons. int. Explor. Mer 183: 126-135

Steemann Nielsen, E. (1952). The use of radioactive carbon $\left({ }^{14} \mathrm{C}\right)$ for measuring organic production in the sea. J. Cons. perm. int. Explor. Mer 18: 117-140

Stoecker, D. K., Egloff, D. A. (1987). Predation by Acartia tonsa Dana on planktonic ciliates and rotifers. J. exp. mar. Biol. Ecol. 110: 53-68

Suttle, C. A., Chan, A. M., Cottrell, M. T. (1990). Infection of phytoplankton by viruses and reduction of primary productivity. Nature 347: 467-469

Tett, P., Edwards, A. (1984). Mixing and plankton: an interdisciplinary theme in oceanography. Oceanogr. mar. Biol. A. Rev. 22: 99-123

Thingstad, T F., Sakshaug, E. (1990). Control of phytoplankton growth in nutrient recycling ecosystems. Theory and terminology. Mar. Ecol. Prog. Ser. 63: 261-272

Utermöhl, H. (1958). Zur Vervollkommnung der quantitativen Phytoplanktonmethodik. Mitt. int. Verein. theor angew. Limnol. 9: 1-38

Wassmann, P. (1991). Dynamics of primary production and sedimentation in shallow fjords and polls of western Norway. Oceanogr. mar. Biol. A. Rev. 29:87-154

Williams, R., Lindley, J. A. (1980). Plankton of the Fladen Ground during FLEX 76 III. Vertical distribution, population dynamics and production of Calanus finmarchicus (Crustacea: Copepoda). Mar. Biol. 60: 47-56

Wulff, F. (1979). The effects of sampling frequency on estimates of the annual pelagic primary production in the Baltic. In: Hytteborn, H. (ed.) The use of ecological variables in environmental monitoring. The National Swedish Environmental Protection Board, Report PM 1151, Stockholm, p. 147-150

Manuscript first received: March 4, 1991

Revised version accepted: December 23, 1992 